\title{
Reaction of Cauliflower Genotypes to Black Rot of Crucifers
}

\author{
Lincon Rafael da Silva ${ }^{1}$, Renan César Dias da Silva ${ }^{1}$, Atalita Francis Cardoso ${ }^{2}$, Gláucia de Mello Pelá ${ }^{1}$, \\ Daniel Diego Costa Carvalho ${ }^{1 *}$ \\ ${ }^{1}$ Laboratory of Plant Pathology, Goiás State University (UEG), Rodovia GO 330, km 241, Anel Viário, Setor Universitário, \\ 75780-000, Ipameri, Goiás, Brazil \\ ${ }^{2}$ Department of Plant Production, Federal University of Uberlândia (UFU), Av. João Naves de Ávila, 2121, Campus Santa \\ Mônica, CP 593, 38408-100, Uberlândia, Minas Gerais, Brazil
}

(Received on January 28, 2015; Revised on March 31, 2015; Accepted on April 13, 2015)

This study aimed to evaluate six cauliflower genotypes regarding their resistance to black rot and their production performance. To do so, it was conducted two field experiments in Ipameri, Goiás, Brazil, in 2012 and 2013. It was used a randomized block design, with four replications (total of 24 plots). Each plot consisted of three planting lines $2.5 \mathrm{~m}$ long (six plants/line), spaced $1.0 \mathrm{~m}$ apart, for a total area of $7.5 \mathrm{~m}^{2}$. Evaluations of black rot severity were performed at 45 days after transplanting, this is, 75 days after sowing (DAS), and yield evaluations at 90 to 105 DAS. The Verona 184 genotype was the most resistant to black rot, showing 1.87 and $2.25 \%$ of leaf area covered by black rot symptom (LACBRS) in 2012 and 2013. However, it was not among the most productive materials. The yield of the genotypes varied between 15.14 and $25.83 \mathrm{t} / \mathrm{ha}$ in both years, Lisvera F1 (21.78 and 24.60 t/ha) and Cindy (19.95 and $23.56 \mathrm{t} / \mathrm{ha}$ ) being the most productive. However, Lisvera F1 showed 6.37 and $9.37 \%$ of LACBRS and Cindy showed $\mathbf{1 4 . 2 5}$ and $\mathbf{1 4 . 8 7 \%}$ of LACBRS in 2012 and 2013, being both considered as tolerant to black rot.

Keywords : Brassica oleracea var. botrytis, disease resistance, plant breeding, Xanthomonas campestris pv. campestris

Cauliflower is very important, particularly for the family farmers who, generally, cultivate small areas throughout the year (Monteiro et al., 2010). According to May et al. (2007), well developed commercial plantations produce 15,000 to 20,000 marketable "heads" per hectare. As each

*Corresponding author.

Phone) +55-64-3491-1556, FAX) +55-64-3491-1556

E-mail)daniel.carvalho@ueg.br plant produces only one head, weighing from 1 to $2 \mathrm{~kg}$, in practice, one gets yields of 15 to 25 tha. The consumption of this vegetable is growing in Brazil, where the product comes from the States of São Paulo and Paraná, which increases the final consumer price (Zanuzo et al., 2013).

Black rot, caused by the Xanthomonas campestris pv. campestris bacterium, is considered the most important disease of crucifers, resulting in considerable yield and quality reductions (Sousa et al., 2003; Seabra Júnior et al., 2013). Even when adapted to the soil and climate conditions, the production of crucifers can be limited by the occurrence of diseases (Peruch et al., 2006). The $X$. campestris pv. campestris bacterium is favored by high temperatures and air humidity, making black rot one of the most destructive diseases of crucifers, mainly in the rain period (Maringoni, 2005; May et al., 2007; Sousa et al., 2003). Black rot occurs in up to $88.9 \%$ of cauliflower plantations, which confirms it is the main disease of crucifers (Peruch et al., 2006). According to Maringoni (2005), the presence of the pathogen is first revealed by the darkening of the parenchyma, located on the leaf edges. Subsequently, the affected area spreads rapidly from the edges to the center of the leaves, resulting in the emergence of "V"-shape chlorotic areas, closing from the edges to the center of the leaf blade.

Black rot can be controlled through healthy propagating material and adoption of agricultural practices that limit bacterial dissemination. However, the most efficient way of controlling the disease is to use resistant cultivars (Villeth et al., 2009). Moreover, the use of resistant cultivars is one of the most sustainable options, in comparison with chemical products used to control various diseases (Rodrigues et al., 2004; Seabra Júnior et al., 2008). Thus, the evaluation of the resistance of cauliflower cultivars to black rot is very important for material recommendation and resistance source selection (Morais Júnior et al., 2012). Such information, associated with the yield performance of the material 
will make it possible to recommend the best material for cultivation in the region where the study was conducted (May et al., 2007). This study aimed at evaluating six cauliflower genotypes regarding their resistance to black rot and their yield performance.

The experiments were conducted in the Goiás State University of Goiás (UEG), Ipameri, Brazil (latitude 17²4' S, longitude $48^{\circ} 11^{\prime} \mathrm{W}$, altitude $800 \mathrm{~m}$ ), in dystrophic red-yellow oxisol with $\mathrm{pH}$ of 7.1. According to soil analysis, $\mathrm{Ca}$, $\mathrm{Mg}, \mathrm{Al}$ and $\mathrm{H}+\mathrm{Al}$ contents were estimated at 2.1, 1.3, 0.0, and $1.5 \mathrm{cmolc} / \mathrm{dm}$. For $\mathrm{P}$ and $\mathrm{K}$ contents, it was founded 9.6 $\mathrm{mg} / \mathrm{dm}$ and $102 \mathrm{mg} / \mathrm{dm}$, respectively. The dates were: experiment 1 (01-16-2012 to 04-28-2012), experiment 2 (0124-2013 to 04-27-2013). At 30 days after sowing (DAS), the seedlings ( 4 to 5 definitive leaves) were transplanted to the experimental area, which received plantation fertilization with $55 \mathrm{~kg} /$ ha of N, $295 \mathrm{~kg} /$ ha of $\mathrm{P}_{2} \mathrm{O}_{5}, 75 \mathrm{~kg} /$ ha of $\mathrm{K}_{2} \mathrm{O}$ and $340 \mathrm{~g} / \mathrm{ha}$ of $\mathrm{B}$. The top-dressing fertilizations $(48 \mathrm{~kg} /$ ha of $\mathrm{N}$ and $83 \mathrm{~kg} /$ ha of $\mathrm{K}_{2} \mathrm{O}$ ) were carried out at 30 and 50 days after transplant (DAT). The crop was drip-irrigated, weed control was made by manual weeding and, pest control was carried out at 7, 14, 21, 28, 35 and 42 DAT, by alternating the following insecticides: Connect ${ }^{\circledR}$ at $500 \mathrm{ml} /$ ha (Imidacloprid $100 \mathrm{~g} / 1$ and Beta-cyfluthrin $12.5 \mathrm{~g} / \mathrm{l}$, Bayer CropScience Ltd.); Decis $25 \mathrm{EC}^{\circledR}$ at $135 \mathrm{ml} / \mathrm{ha}$ (Deltamethrin $25 \mathrm{~g} / 1$, Bayer CropScience Ltd.) and Ampligo ${ }^{\circledR}$ at 150 $\mathrm{ml} /$ ha (Lambda-Cyhalothrin $50 \mathrm{~g} / 1$ and Chlorantraniliprole $100 \mathrm{~g} / \mathrm{l}$, Syngenta AG). The six evaluated genotypes were (a) five hybrid: Sarah AF 1169, Sharon, Cindy (Sakata Seed Sudamerica Ltda.), Lisvera F1 (Clause Brasil Comércio de Sementes Ltda.), Verona 184 (Seminis Vegetable Seeds, Inc.); and (b) one open pollinated/black rot resistant material: Piracicaba Precoce (ISLA Sementes Ltda.). It was used a randomized block design (RBD), with six treatments and four replications, for a total of 24 plots. Each plot consisted of three planting lines $2.5 \mathrm{~m}$ long (six plants/line), spaced $1.0 \mathrm{~m}$ apart, for a total area of $7.5 \mathrm{~m}^{2}$. The evaluations of black rot severity and productivity were carried out in both experiments. No inoculations of $X$. campestris pv. campestris were made, which black rot occurred naturally in both experiments.

The evaluation of the resistance of the genotypes to black rot was carried out at the critical plant development stage for the disease, this is, 75 DAS, using an adapted grade scale of Henz and Melo (1994), as follows: Grade 0: Leaves without black rot symptoms (BRS); Grade 1: Plants with up to $15 \%$ of leaves with BRS, one or two small lesions (up to $1.5 \mathrm{~cm}$ in diameter); Grade 2: Plant with 15 to $30 \%$ of leaves with BRS; three to five medium lesions ( 1.5 to $4.0 \mathrm{~cm}$ in diameter); Grade 3: Plant with 30 to $50 \%$ of leaves with BRS; five or more large lesions $(>4.0 \mathrm{~cm}$ in diameter); Grade 4: Plant with 50 to $75 \%$ of leaves with BRS; presence of coalesced lesions and leaf blight and; Grade 5: Plant with 75 to $100 \%$ of leaves with BRS or dead plant. Thus, for evaluation of black rot severity, five plants of the main line were used randomly for each plot. For statistical analyses, the mid-point of each attributed grade was taken into account, which allowed to express the results in percentage of injured leaf area.

For evaluation of the productivity and its components, the harvest was carried out between 90 and 105 DAS. For the evaluations, it was considered the six plants of the plot's central line. Thus, the evaluated characteristics were: (1) average number of leaves per plant (NLP), (2) average diameter of the stem (DS), (3) average transversal diameter of the head (TD), (4) average height of the head ( $\mathrm{HH})$ and, (5) productivity (PRO).

Results were submitted to analysis of variance and ScottKnott test $(P \leq 0.05)$, using the statistical software SISVAR 5.3 (Ferreira, 2011).

In the evaluation of black rot severity in 2012, the disease was statistically less severe in the Verona 184 genotype, with only $1.87 \%$ of the leaf area covered by black rot symptom (LACBRS), whereas the other genotypes had between 4.87 and $14.25 \%$ of LACBRS (Table 1). On the other hand, in the evaluation of severity in 2013, the disease was again statistically less severe in the Verona 184 genotype, with $2.25 \%$ of LACBRS, however not differing from the Sharon genotype, which showed 3.75\% of LACBRS. The other genotypes stood in statistically higher

Table 1. Severity (leaf area covered by black rot symptoms) at 75 DAS in six cauliflower genotypes, Ipameri, Goiás, Brazil, 2012$2013^{\mathrm{a}}$

\begin{tabular}{lcc}
\hline \multirow{2}{*}{ Genotype } & \multicolumn{2}{c}{$\begin{array}{c}\text { Severity: leaf area covered by } \\
\text { black rot symptom }(\%)^{\mathrm{a}}\end{array}$} \\
\cline { 2 - 3 } & 2012 & 2013 \\
\hline Verona 184 & $1.87 \mathrm{aA}$ & $2.25 \mathrm{aA}$ \\
Sharon & $4.87 \mathrm{bA}$ & $3.75 \mathrm{aA}$ \\
Lisvera F1 & $6.37 \mathrm{bA}$ & $9.37 \mathrm{cB}$ \\
Piracicaba Precoce & $7.87 \mathrm{bA}$ & $7.12 \mathrm{bA}$ \\
Sarah AF 1169 & $13.25 \mathrm{cA}$ & $12.37 \mathrm{dA}$ \\
Cindy & $14.25 \mathrm{cA}$ & $14.87 \mathrm{dA}$ \\
\hline Average & $8.08 \mathrm{~A}$ & $8.29 \mathrm{~A}$ \\
\hline Coefficient of variation $(\%)^{\mathrm{b}}$ & 26.28 & 22.37 \\
\hline
\end{tabular}

${ }^{a}$ Averages followed by the same lower case letters in the columns and upper case letters in the lines do not differ statistically, according Scott-Knott test $(P \leq 0.05)$; ${ }^{b}$ General severity average for all genotypes. 
Table 2. Average number of leaves per plant (NLP), average diameter of the stem (DS), average transversal diameter of the head (TD), average height of the head $(\mathrm{HH})$ and productivity (PRO), of six cauliflower genotypes, Ipameri, Goiás, Brazil, 2012-2013 ${ }^{\mathrm{a}}$

\begin{tabular}{|c|c|c|c|c|c|c|c|c|c|c|}
\hline \multirow{2}{*}{ Genotype } & \multicolumn{2}{|c|}{ NLP } & \multicolumn{2}{|c|}{$\mathrm{DS}(\mathrm{cm})$} & \multicolumn{2}{|c|}{$\mathrm{TD}(\mathrm{cm})$} & \multicolumn{2}{|c|}{$\mathrm{HH}(\mathrm{cm})$} & \multicolumn{2}{|c|}{ PRO (t/ha) } \\
\hline & 2012 & 2013 & 2012 & 2013 & 2012 & 2013 & 2012 & 2013 & 2012 & 2013 \\
\hline Verona 184 & $26.03 \mathrm{aA}$ & $21.95 \mathrm{bB}$ & $3.26 \mathrm{aA}$ & $3.43 \mathrm{aA}$ & $18.88 \mathrm{aA}$ & $18.99 \mathrm{aA}$ & $10.72 \mathrm{aA}$ & $11.74 \mathrm{aA}$ & $18.39 \mathrm{bB}$ & $25.83 \mathrm{aA}$ \\
\hline Sharon & $25.33 \mathrm{aA}$ & $20.79 \mathrm{bB}$ & $3.30 \mathrm{aA}$ & $3.26 \mathrm{aA}$ & $17.98 \mathrm{aA}$ & $19.16 \mathrm{aA}$ & $10.84 \mathrm{aA}$ & $11.49 \mathrm{aA}$ & $16.89 \mathrm{bB}$ & $24.86 \mathrm{aA}$ \\
\hline Lisvera F1 & $24.01 \mathrm{aA}$ & $23.99 \mathrm{aA}$ & $3.41 \mathrm{aA}$ & $3.20 \mathrm{aA}$ & $18.61 \mathrm{aA}$ & $17.87 \mathrm{aA}$ & $11.03 \mathrm{aA}$ & $11.33 \mathrm{aA}$ & $21.78 \mathrm{aA}$ & $24.60 \mathrm{aA}$ \\
\hline P. Precoce & $20.74 \mathrm{bA}$ & $21.62 \mathrm{bA}$ & $3.03 \mathrm{aA}$ & $3.10 \mathrm{bA}$ & $19.30 \mathrm{aA}$ & $18.82 \mathrm{aA}$ & $11.39 \mathrm{aA}$ & $10.49 \mathrm{aA}$ & $15.14 \mathrm{bA}$ & $15.84 \mathrm{cA}$ \\
\hline Sarah AF 1169 & $27.91 \mathrm{aA}$ & $24.58 \mathrm{aB}$ & $2.87 \mathrm{aA}$ & $2.90 \mathrm{bA}$ & $19.12 \mathrm{aA}$ & $16.74 \mathrm{aB}$ & $10.56 \mathrm{aA}$ & $10.29 \mathrm{aA}$ & $17.94 \mathrm{bA}$ & $18.98 \mathrm{bA}$ \\
\hline Cindy & $24.25 \mathrm{aA}$ & $23.03 \mathrm{aA}$ & $3.21 \mathrm{aA}$ & $3.20 \mathrm{aA}$ & $19.62 \mathrm{aA}$ & $18.20 \mathrm{aA}$ & $12.10 \mathrm{aA}$ & $11.49 \mathrm{aA}$ & $19.95 \mathrm{aB}$ & $23.56 \mathrm{aA}$ \\
\hline $\begin{array}{l}\text { Coefficient of } \\
\text { variation }(\%)\end{array}$ & 6.99 & 6.43 & 8.20 & 4.46 & 7.55 & 7.02 & 9.47 & 7.40 & 12.14 & 6.72 \\
\hline
\end{tabular}

${ }^{a}$ Averages followed by the same lower case letters in the columns and upper case letters in the lines do not differ statistically, according to ScottKnott test $(P \leq 0.05)$.

ranges of LACBRS, with percentages varying between 7.12 and $14.87 \%$. All genotypes kept similar percentages of LACBRS in both crop years, except Lisvera F1. This genotype had a significant increase in LACBRS (\%) from 2012 $(6.37 \%)$ to $2013(9.37 \%)$.

The evaluation of NLP in 2012 showed no statistical difference between genotypes, except for Piracicaba Precoce, which had a lower NLP than the other treatments (Table 2). In 2013, on the other hand, Lisvera F1, Sarah AF 169 and Cindy differed from the other genotypes, showing a statistically higher NLP (23.99, 24.58 and 23.03, respectively). Lisvera F1, Piracicaba Precoce and Cindy kept similar percentages of NLP in both crop years, whereas Verona 184, Sharon and Sarah AF 1169 showed lower values of NLP in $2013(21.95,20.79$ and 24.58, respectively) than in 2012 (26.03, 25.33 and 27.91, respectively).

In 2012, there was no difference between the genotypes as regards DS, whereas in 2013, Verona 184, Sharon, Lisvera F1 and Cindy were statistically superior to Piracicaba Precoce and Sarah AF 1169. In both harvests, the genotypes did not differ as regards TD and $\mathrm{HH}$.

Regarding productivity, only Lisvera F1 and Cindy were superior to the other genotypes in both crop years. In 2012, these genotypes produced 21.78 and $19.95 \mathrm{t} / \mathrm{ha}$, respectively. In 2013, the productivity was 24.60 and 23.56 t/ha, respectively. In 2013, the productivity of Verona 184 and Sharon was similar to that of Lisvera F1 and Cindy. However, in 2012 such fact was not confirmed. Lisvera F1 was more stable than Cindy, as it showed no significant difference of productivity in both crop years.

Aiming to compare the genotypes (Sarah AF 1169, Sharon, Cindy, Lisvera F1 and Verona 184) with a material without the disease, the black rot resistant genotype Piracicaba Precoce was included in this study. However, these plants were also affected by the disease. Therefore, there is not resistant material for the Ipameri region.

In this study, attention was paid to the repetition of the tests, in two harvests: experiment 1 (01-16-2012 to 04-282012), experiment 2 (01-24-2013 to 04-27-2013), since the indication of cauliflower cultivars on the basis of the averages of the production traits and disease resistance traits when evaluated in only one harvest are not totally consistent (Morais Júnior et al., 2012). The same authors show the importance of conducting more studies about the performance of cauliflower genotypes for various Brazilian regions, particularly those evaluated in more than one harvest. According Jensen et al. (2005), the symptoms appeared in the field at 60 DAS. Therefore, attempts has been made to the evaluation of the resistance of the genotypes to black rot, which was carried out at the critical plant development stage for the disease (75 DAS).

Morais Júnior et al. (2012) evaluated the same materials as the present study during the 2008/2009 harvest and verified that the Cindy genotype showed a higher black rot severity than the other materials. However, it was among the most productive (yield was $31.2 \mathrm{t} / \mathrm{ha}$ ). After evaluation in both harvests (2012 and 2013), Cindy has proven tolerant to black rot, since it showed the highest severity rate among the genotypes (14.25\% and $14.87 \%$ of LACBRS in 2012 and 2013, respectively), being even so among the most productive genotypes in both years (19.95 and 23.56 ton/ha in 2012 and 2013, respectively). The data obtained in the present study, associated with those obtained by Morais Júnior et al. (2012), do not agree with Santos et al. (2008), who classified the Cindy genotype as moderately resistant. Jiang et al. (2011) reported that not only resistant genotypes, but also susceptible ones possess defense response mechanisms. However, on the basis of the results 
presented in Tables 1 and 2 of the present study, tolerance is a term more appropriate to the Cindy genotype.

Traits related to vegetal production are subject to the genetic control of the organism and to the environment where it is cultivated, as well as to the interaction between these two factors and, as is well known, a genotype can suffer environmental impact according to the evaluated year (Annicchiarico, 2002). In this context, it is important to point out that all genotypes showed stability during both years, regarding their reaction to black rot. The only exception was Lisvera F1, which had a significant increase in LACBRS from the first to the second crop year, being the only one that suffered environmental impact.

According to Jensen et al. (2005) and Santos et al. (2008), diverse races of $X$. campestris pv. campestris have already been recorded, indicating the existence of pathogenic variability. Verona 184 stood out from the other genotypes due to a lower and significant LACBRS rate, which suggests that the genetic variability obtained in the pathogen population was not enough to break the resistance of the genotype from one year to the other. What is known about $X$. campestris pv. campestris is that a population can be spontaneously recombined. In Brazil, however, there is no report of resistance breakdown from one year to the other, especially due to the lack of information about the pathosystem $X$. campestris pv. campestris-crucifers (Santos et al., 2008).

Regarding NLP, it was found that Lisvera F1, Sarah AF 1169 and Cindy showed higher averages in both evaluation years (Table 2). In other studies with similar purposes, different results were found regarding the average number of leaves, sometimes higher (Monteiro et al., 2010), sometimes lower (Godoy and Cardoso, 2005). Genetic improvement has tried to improve the production potential of various crops by taking account of their ideotype. With an increase in the number of leaves, one could obtain an increase in the leaf area index, resulting in higher photosynthetic capacity, provided one considers an insertion angle of the superior leaves, of the erect type (May et al., 2007). In the case of the present study, it do not point out any abnormality regarding NLP, since the productivity of the materials varied between 15.14 and $25.83 \mathrm{t} / \mathrm{ha}$, which is considered normal for cauliflower, whose production potential varies between 15 and 25 t/ha (May et al., 2007).

Besides not being the most productive genotypes in 2012, Piracicaba Precoce and Sarah AF 1169 had a significantly lower productivity ( $\mathrm{t} / \mathrm{ha}$ ) than other genotypes in 2013. This can be explained by the fact that these two genotypes also differed from the others regarding DS in 2013. According to Monteiro et al. (2010), thicker stems, besides being more capable for supporting heavier heads, can also present higher productivity, since they show a higher number of transport vessels for translocation of water and photoassimilates. Still regarding productivity, attention must be paid to Verona 184, Sharon and Cindy, which varied significantly from one year to the other, which suggests that these three genotypes were those which were most affected by the environmental impact on the productivity ( $t / h a)$ trait. In this respect, Lisvera F1 stood out from the others due to be the only one among the most productive genotypes in both crop years and did not suffer productivity alterations.

Camargo et al. (2008) evaluated the productivity of the Sharon genotype and observed an average of $18.36 \mathrm{t} / \mathrm{ha}$. Considering this value, one gets that this genotype showed a productivity average lower in 2012 (16.89 t/ha) and higher in 2013 (24.86 t/ha), which confirms that it suffered environmental impact on the productivity trait. Considering the average of $15.47 \mathrm{t} /$ ha found by Castoldi et al. (2009) in their genotypes, the productivity values showed in Table 2 of the present study are higher; however, if compared to Morais Júnior et al. (2012), (average of $30.45 \mathrm{t} / \mathrm{ha}$ ) they are lower. This occurs because productivity, influenced by the resistance of the plants to black rot, consists of a complex systematic process, including biological and biochemical components in the expression of the resistance of the genes and in the common mechanisms of reaction to abiotic stress (Jiang et al., 2011).

Regarding TD, the genotypes did not differ statistically in any of the crop years. However it was found that for Sarah AF 1169, TD was significantly lower in 2013, which suggests that this trait shows some sensitivity to environmental changes, but does not allow generalizations about the standard of a particular cultivar for this trait (Morais Júnior et al., 2012). Although the genotypes did not differ regarding $\mathrm{TD}$, this trait is relevant, since cultivars with larger heads are more appreciated, due to fitting into the higher classes of the classification rules (Hortbrasil, 2011).

No difference between genotypes was found in the evaluation of $\mathrm{HH}$. This trait was evaluated because, together with DS, it gives some insight of the head shape, which also influences the commercial value (Monteiro et al., 2010). HH values found by Godoy and Cardoso (2005) were higher $(13.7 \mathrm{~cm})$. One of the factors explaining this difference could rely on the difference of genotypes and growing site.

Verona 184 presented a lower black rot severity than the other genotypes, in both crop years, with no statistical difference of severity from one year to the other. However, it was not among the most productive genotypes, considering the two years. Lisvera F1 and Cindy were the most productive genotypes in both crop years. However, Lisvera F1 
stood out for not having suffered productivity alterations from one year to the other. Besides, Lisvera F1 presented a lower black rot severity than Cindy in both years. Finally, among the six genotypes, Lisvera F1 and Cindy can be considered as tolerant to black rot. Cindy for being among the most productive genotypes in both years, although being the most affected by black rot, and Lisvera F1 for keeping its productivity constant, even with the increase in the severity of the disease in 2013. Therefore, the conclusions of this study are: (1) Lisvera F1 and Cindy are the most productive genotypes, besides showing a tolerant behavior to black rot and (2) The Verona 184 genotype is the most resistant to black rot, being recommended for crop rotation.

\section{Acknowledgments}

The authors thank the Goiás State University (UEG) for a fellowship and the Incentive fellowship program for research and scientific production (PROBIP-UEG) by the financial support and in the elaboration of the article.

\section{References}

Annicchiarico P. 2002. Genotype $\times$ environment interaction: challenges and opportunities for plant breeding and cultivar recommendations. Rome: FAO.

Camargo, M. S., Mello, S. C., Foltran, D. E. and Carmello, Q. A. C. 2008. Produtividade e podridão parda em couve-flor de inverno influenciadas pelo nitrogênio e boro. Bragantia 67:371-375.

Castoldi, R., Charlo, H. C. O., Vargas, P. F. and Braz, L. T. 2009. Crescimento, acúmulo de nutrientes e produtividade da cultura da couve-flor. Hortic Bras. 27:438-446.

Ferreira, D. F. 2011. Sisvar: a computer statistical analysis system. Cienc. Agrotec. 35:1039-1042.

Godoy, M. C. and Cardoso, A. I. I. 2005. Produtividade da couveflor em função da idade de transplantio das mudas produzidas e tamanhos de células na bandeja. Hortic Bras. 23:837-840.

Henz, G. P. and Melo, P. E. 1994. Resistência de cultivares de repolho à Xanthomonas campestris pv. campestris. Pesqui. Agropecu. Bras. 29:411-415.

Hortbrasil. 2014. Normas de classificação - couve-flor. Campinas, 2011. Available at: <http://www.hortibrasil.org.br/jnw/classificacao/couveflor/couveflor.html>. Acess on: 21 June 2014.

Jensen, B. D., Massomo, S. M. S., Swai, I. S., Hockenhull, J. and Andersen, S. B. 2005. Field evaluation for resistance to the black rot pathogen Xanthomonas campestris pv. campestris in cabbage (Brassica oleracea). Eur. J. Plant. Pathol. 113:297308.

Jiang, H., Song, W., Yang, A. L. X. and Sun, D. 2011. Identification of genes differentially expressed in cauliflower associated with resistance to Xanthomonas campestris pv. campestris. Mol. Biol. Rep. 38:621-629.

Maringoni, A. C. 2005. Doenças das crucíferas. In: Kimati, H., Amorim, L., Rezende, J. A. M. and Bergamin Filho, A. Manual de fitopatologia. São Paulo: Agronômica Ceres, pp. 285292.

May, A., Tivelli, S. W., Vargas, P. F., Samra, A. G., Sacconi, L. V. and Pinheiro, M. Q. 2007. A cultura da couve-flor. Boletim Técnico. Campinas: Instituto Agronômico de Campinas.

Monteiro, B. C. B. A., Charlo, H. C. O. and Braz, L. T. 2010. Desempenho de híbridos de couve-flor de verão em Jaboticabal. Hortic Bras. 28:115-119.

Morais Júnior, O., Cardoso, A. F., Leão, E. F. and Peixoto, N. 2012. Desempenho de cultivares de couve-flor de verão em Ipameri. Cienc. Rural. 42:1923-1928.

Peruch, L. A. M., Michereff, S. J. and Araújo, I. B. 2006. Levantamento da intensidade da alternariose e da podridão negra em cultivos orgânicos de brássicas em Pernambuco e Santa Catarina. Hortic. Bras. 24:464-469.

Rodrigues, V. J. L. B., Michereff, S. J., Aguiar Filho, M. R., Silva, L. G. C. and Biondi, C. M. 2004. Epidemiologia comparativa da alternariose em cultivares de brássicas sob cultivo convencional e orgânico. Summa Phytopathol. 30:226-233.

Santos, L. A., Bandeira, D. A., Silva, J. P., Silveira, E. B., Gomes, A. M. A. and Mariano, R. L. R. 2008. Caracterização de isolados de Xanthomonas campestris pv campestris de sistemas de produção orgânico e reação de brássicas à podridão-negra. Hortic Bras. 26:486-491.

Seabra Júnior, S., Lalla, J. G., Goto, R., Maringoni, A. C., Villas Boas, R. L., Rouws, J. R. C. and Oriani, E. E. 2013. Suscetibilidade à podridão negra e produtividade de brócolis em função de doses de nitrogênio e potássio. Hortic Bras. 31:426-431.

Seabra Júnior, S., Paixão, G. S., Maringoni, A. C., Goto, R. and Camara, R. C. 2008. Reação de híbridos de brócolis 'tipo cabeça única’ à podridão negra. Summa Phytopathol. 34:76-77.

Sousa, C. S., Haber, L. L., Santana, D. G., Arruda, A. S. and Takatsu, A. 2003. Método de inoculação de Xanthomonas campestris pv. campestris pelo sistema radicular para avaliação rápida de resistência de repolho à podridão negra. Biosci. J. 19:53-56.

Villeth, G. R., Reis Junior, F. B., Tonietto, A., Huergo, L., Souza, E. M., Pedrosa, F. O., Franco, O. L. and Mehta, A. 2009. Comparative proteomeanalysis of Xanthomonas campestris pv. campestris in the interaction with the susceptible and the resistant cultivars of Brassica oleracea. FEMS Microbiol. Lett. 298:260-266.

Zanuzo, M. R., Ribeiro, L. M., Lange, A., Machado, R. A. F. and Massaroto, J. A. 2013. Desempenho agronômico de genótipos de couve-flor nas condições edafoclimáticas de Sinop. Hortic. Bras. 31:332-337. 